\title{
Pengukuran Scaling pada Pipa menggunakan Tomografi Gamma Parallel Beam
}

\section{Measurement of Pipe Scaling using Parallel Beam Gamma Tomography}

\author{
Bayu Azmi ${ }^{1}$, Wibisono ${ }^{1}$ dan Adhi Harmoko Saputro ${ }^{2}$ \\ ${ }^{1}$ Pusat Aplikasi Isotop dan Radiasi, BATAN \\ Jl. Lebak Bulus Raya No. 49, Jakarta Selatan 12440 \\ ${ }^{2}$ Departemen Fisika, Universitas Indonesia, Depok, 16424 \\ Email : bayuazmi@batan.go.id
}

\begin{abstract}
ABSTRAK
Pembentukan scale pada pipa maupun unit proses lainnya dapat terjadi di dalam proses produksi. Scaling pada pipa dapat mengurangi diameter pipa sehingga mengurangi laju alir dan bahkan mengakibatkan pipa tersumbat. Pengukuran diperlukan untuk mengetahui keberadaan dan persentase scaling pada pipa. Tomografi merupakan teknik yang digunakan untuk menginvestigasi struktur dalam suatu obyek secara non-intrusive dan non-invasive. Dalam penelitian ini sistem tomografi digunakan untuk pemindaian translasi dan rotasi secara otomatis. Sumber radiasi gamma ${ }^{137} \mathrm{Cs}$ yang terkolimasi mentransmisikan foton gamma menembus obyek uji yang kemudian dideteksi dengan detektor sintilasi $\mathrm{NaI}(\mathrm{Tl})$. Kumpulan data proyeksi dibangun menjadi citra menggunakan perekonstruksi citra dengan metode filtered back projection (FBP). Citra hasil rekonstruksi dapat membedakan material dengan nilai densitas yang berdekatan seperti air $\left(1 \mathrm{~g} / \mathrm{cm}^{3}\right)$, parafin $\left(0,9 \mathrm{~g} / \mathrm{cm}^{3}\right)$, dan pertalite $\left(0,72-0,77 \mathrm{~g} / \mathrm{cm}^{3}\right)$. Citra pipa dengan scale dianalisis untuk menghitung persentase area aliran setelah terjadi scaling terhadap pipa normal (pipa tanpa scale). Hasil analisis citra area aliran yang tersisa pada pipa geothermal plant adalah $10,06 \%$ dengan 16 proyeksi, 9,86\% dengan 32 proyeksi, $9,75 \%$ dengan 64 proyeksi, dan $9,76 \%$ dengan 128 proyeksi, sedangkan $26,08 \%$ pada pipa furnace dengan 32 proyeksi. Sistem yang telah dibangun berhasil memindai obyek, mengakuisisi dan mengumpulkan data, serta membangun dan menganalisis citra untuk menginvestigasi scale di dalam pipa.
\end{abstract}

Kata Kunci : industri, pipe scaling, parallel beam, rekonstruksi citra, tomografi gamma

\begin{abstract}
Scaling in pipeline or other process units may occur in the production process. Scaling in pipes can reduce the diameter of the pipe, thereby reducing the flow rate and even lead to clogged pipes. Measurement is needed to determine the existence of scaling and its percentage. Tomography is a technique used to investigate the inner structure of an object in a non-intrusive and non-invasive. In this work tomography system was used to conduct translational and rotational scan automatically. Collimated gamma-ray source ${ }^{137} \mathrm{Cs}$ transmit photons through the object and detected using $\mathrm{NaI}(\mathrm{Tl})$ scintillation detector. The projections data was built to image using filtered back projection (FBP) image reconstruction method. The reconstructed image is able to distinguish materials with adjacent density value such as water $\left(1 \mathrm{~g} / \mathrm{cm}^{3}\right)$, paraffin $\left(0.9 \mathrm{~g} / \mathrm{cm}^{3}\right)$, and pertalite $\left(0.72-0.77 \mathrm{~g} / \mathrm{cm}^{3}\right)$. The pipes within scale image were analyzed to calculate percentage of flow area after scaling compared to normal pipe (pipe without scale). The image analysis results of remaining flow area in geothermal plant pipe are $10.06 \%$ with 16 projections, $9.86 \%$ with 32 projections, $9.75 \%$ with 64 projections, and $9.76 \%$ with 128 projections, while $26.08 \%$ is in furnace pipe with 32 projections. Finally, the system successfully scans the object, acquires and collects data, builds and analyzes the image for pipe scale investigation.
\end{abstract}

Keywords : gamma tomography, image reconstruction, industry, parallel beam, pipe scaling

\section{PENDAHULUAN}

Sistem multifase adalah struktur yang terdiri dari campuran padatan, cairan, dan gas di dalam reaktor kimia atau pipa dalam proses dinamis [1]. Scaling pada pipa maupun unit lainnya dapat mengganggu proses produksi. Scale didefinisikan sebagai senyawa-senyawa anorganik 
yang terendapkan dan membentuk timbunan kristal pada permukaan suatu substansi [2].

Beberapa jenis scaling teramati di dalam sumur dan instalasi Pembangkit Listrik Tenaga Panas Bumi (PLTP). Scaling yang paling umum terdapat di pipa-pipa panas bumi adalah silica $\left(\mathrm{SiO}_{2}\right)$ dan calcite $\left(\mathrm{CaCO}_{3}\right)$ [3]. Scale juga terjadi pada proses pendistribusian minyak mentah (crude oil). Scale yang umum dijumpai pada ladang minyak ditunjukkan pada Tabel 1 . Penyebab langsung terbentuknya scale adalah penurunan tekanan, perubahan temperatur, dan bercampurnya dua macam mineral yang berbeda [4]. Terganggunya aliran fluida akibat scale pada pipa, dapat menyebabkan kenaikan tekanan dan suhu yang memungkinkan pipa akan pecah.

Kemampuan untuk melihat bagian dalam obyek merupakan hal yang sangat dibutuhkan dalam proses industri untuk mendiagnosis malfungsi ataupun dalam rangka peningkatan produksi. Untuk melihat bagian dalam obyek tanpa harus merusak maupun menghentikan proses dibutuhkan suatu teknik yang dapat menembus dan membawa informasi yang dibutuhkan dari obyek tersebut. Radiasi gamma telah banyak digunakan pada proses industri untuk telah banyak diaplikasikan di bidang kesehatan. Aplikasi teknik tomografi di bidang industri memiliki tantangan tersendiri. Sistem tomografi tersebut harus dapat disesuaikan terhadap obyek yang akan diinvestigasi maupun kondisi sekitarnya dan juga mudah untuk dipindahkan (portabel). Pengembangan teknik seperti penggunaan banyak detektor dan menggunakan sumber yang berotasi telah dilakukan untuk diaplikasikan pada industri skala besar [7]. Sistem tomografi yang dapat dipindah (transportable) juga dikembangkan untuk memenuhi kebutuhan industri [8].

Data hasil pemindaian direkonstruksi menjadi citra menggunakan metode fitlered back projection (FBP). Citra hasil rekonstruksi dianalisis untuk mendapatkan area aliran fluida yang tersisa akibat scale. Bentuk pipa pada citra diidentifikasi dengan menggunakan fungsi pengenalan tepi (boundary recognition). Dengan didapatkannya batas luar dan batas dalam obyek, maka total area dalam obyek dapat dihitung. Kemudian, persentase area alir fluida yang tersisa pada pipa yang mengalami scaling dibanding dengan pipa normal (tanpa scale) dapat ditentukan.

Tabel 1. Scale yang umum dijumpai pada ladang minyak [4]

\begin{tabular}{|c|c|c|}
\hline Nama & Formula Kimia & Variabel Primer \\
\hline Calcium Carbonat (Calcite) & $\mathrm{CaCO}_{3}$ & $\begin{array}{l}\text { Suhu parsial } \mathrm{CO}_{2} \text {, suhu total } \\
\text { garam terlarut }\end{array}$ \\
\hline $\begin{array}{l}\text { Calcium Sulfat } \\
\text { Gypsum }\end{array}$ & $\begin{array}{l}\mathrm{CaSO}_{4} \cdot \mathrm{H}_{2} \mathrm{O} \\
\mathrm{CaSO}_{4} \cdot 1 / 2 \mathrm{H}_{2} \mathrm{O}\end{array}$ & $\begin{array}{l}\text { Suhu, total garam terlarut, } \\
\text { tekanan }\end{array}$ \\
\hline $\begin{array}{l}\text { Hemi-hydrate } \\
\text { Anhydrate }\end{array}$ & $\mathrm{CaSO}_{4}$ & \\
\hline $\begin{array}{l}\text { Barium Sulfat } \\
\text { Strontium Sulfat }\end{array}$ & $\begin{array}{l}\mathrm{BaSO}_{4} \\
\mathrm{SrSO}_{4} \\
\end{array}$ & $\begin{array}{l}\text { Suhu, total garam terlarut, } \\
\text { tekanan }\end{array}$ \\
\hline Iron Compound & & Karat, gas terlarut, pH \\
\hline Ferrous Carbonat & $\mathrm{FeCO}_{3}$ & \\
\hline Ferrous Sulfite & $\mathrm{FeS}$ & \\
\hline Ferrous Hydroxide & $\mathrm{Fe}(\mathrm{OH})_{2}$ & \\
\hline Ferric Hydroxide & $\mathrm{Fe}(\mathrm{OH})_{2}$ & \\
\hline Ferric Oxide & $\mathrm{Fe}_{2} \mathrm{O}_{3}$ & \\
\hline
\end{tabular}

mendiagnosis malfungsi pada unit produksi karena energinya yang tinggi dan tidak membutuhkan pembangkit radiasi [5].

Tomografi merupakan pencitraan tampang lintang sebuah obyek dari data transmisi maupun refleksi yang didapat dengan mengukur obyek dari banyak arah yang berbeda [6]. Teknik tomografi

\section{BAHAN DAN METODE}

\section{Bahan dan peralatan}

Obyek pipa dengan scale menggunakan potongan pipa dari pembangkit listrik tenaga panas bumi (PLTP) dan pipa furnace ditunjukkan pada Gambar 1. Selain itu, sampel air, parafin, dan 
pertalite digunakan untuk menguji kemampuan sistem tomografi dalam hal membedakan material yang memiliki nilai densitas yang berdekatan. Nilai densitas air, parafin, dan pertalite berturutturut adalah $1 \mathrm{~g} / \mathrm{cm}^{3}, 0,9 \mathrm{~g} / \mathrm{cm}^{3}$, dan $0,72-0,77$ $\mathrm{g} / \mathrm{cm}^{3}$. diakuisisi dan direkam pada personal komputer. Sistem pemindai dan akuisisi data seperti ditunjukkan pada Gambar 2. Proses dimulai dari pemindaian translasi (sudut $0^{\circ}$ ), yaitu sumber dan detektor gamma bergerak secara bersamaan pada gantry. Intensitas radiasi yang tertangkap oleh

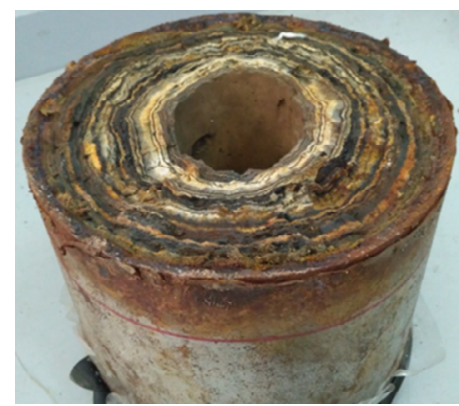

(a)

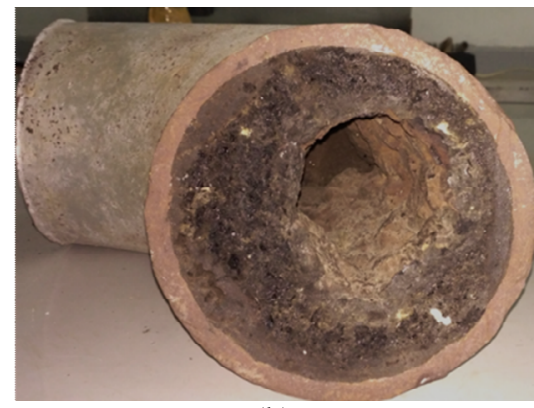

(b)

Gambar 1. Sampel pipa dengan scale, (a) pipa PLTP, (b) pipa furnace.

Sumber radiasi gamma yang digunakan adalah ${ }^{137} \mathrm{Cs}$ dengan aktivitas $80 \mathrm{mCi}$. Energi dari ${ }^{137} \mathrm{Cs}$ adalah sebesar $0,662 \mathrm{MeV}$, sehingga cukup baik untuk digunakan dalam membedakan densitas bahan. Detektor Ludlum Model 44-2 Gamma Scintillator digunakan sebagai pendeteksi foton gamma yang kemudian dicacah menggunakan pencacah radiasi Ludlum Model 2200 Scaler Ratemeter.

\section{Pengambilan data}

Sistem pemindai terdiri dari gantry, aktuator, dan pengendali. Data pemindaian detektor adalah intensitas radiasi yang ditransmisikan oleh sumber radiasi dikurangi oleh radiasi yang telah diserap oleh udara dan atau obyek pada perjalannya menuju detektor [9]. Gerak translasi berhenti setiap $5 \mathrm{~mm}$ dan sistem akan mencacah radiasi. Setelah proses pencacahan radiasi selesai dan data telah disimpan di personal komputer, maka sumber dan detektor bergerak translasi sejauh $5 \mathrm{~mm}$ berikutnya sampai seluruh obyek terpindai.

Data hasil pemindaian translasi sudut $0^{\circ}$ menjadi data proyeksi pertama. Untuk membangun sebuah citra dari data pemindaian

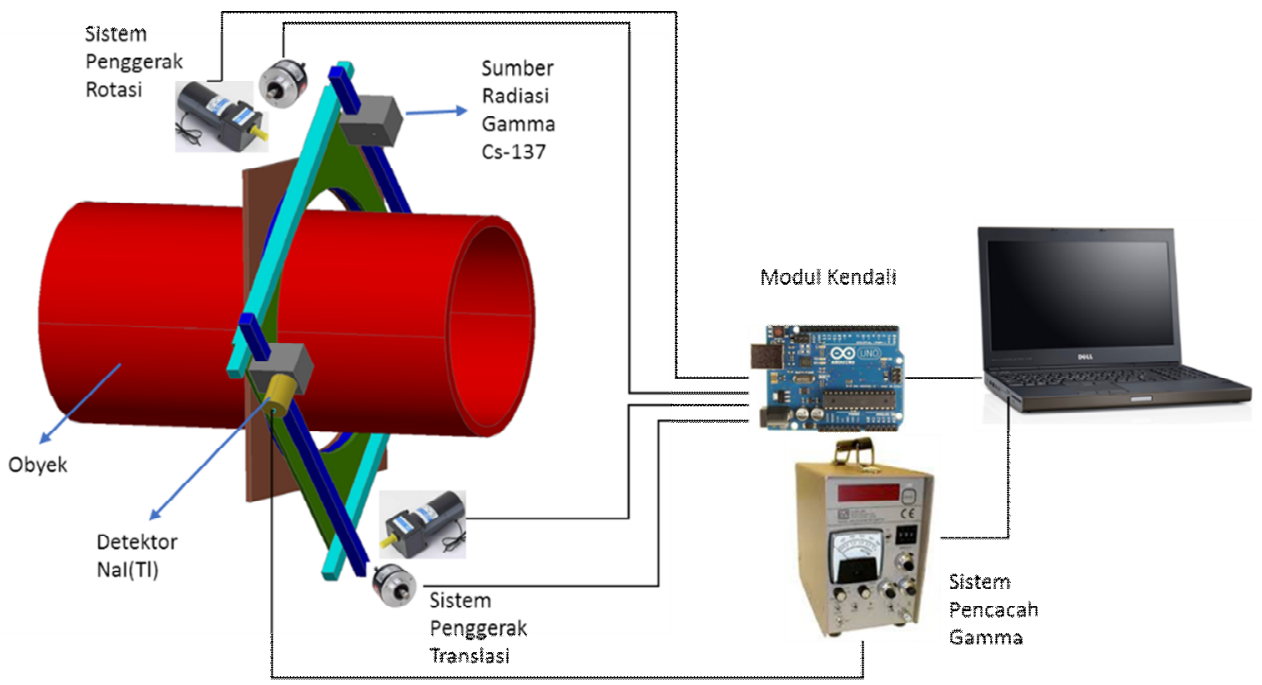

Gambar 2. Diagram sistem pemindai dan akuisisi data 
dibutuhkan beberapa proyeksi. Pada penelitian ini sistem memindai separuh dari obyek $\left(180^{\circ}\right)$. Jika ditentukan akan membangun citra dari 32 proyeksi, artinya pada proyeksi kedua dan seterusnya, gantry melakukan gerak rotasi dengan interval $180^{\circ} / 32=5,625^{\circ}$. Semakin banyak jumlah proyeksi maka akan meningkatkan resolusi spasial dari citra akan tetapi akan membutuhkan waktu yang lebih lama untuk pengambilan data [10].

\section{Rekonstruksi dan analisis citra}

Perangkat lunak perekonstruksi citra pada penelitian ini menggunakan algoritma Filtered Back Projection (FBP). Metode FBP merupakan teknik yang paling dikenal dalam hal rekonstruksi citra karena mudah dikombinasikan dengan akurasi yang baik [11]. Proyeksi dapat dinyatakan sebagai transformasi radon dari objek yang akan direkonstruksi. Transformasi radon dinyatakan sebagai berikut:

$$
p(s, \theta)=R(f)=\int_{-\infty}^{\infty} \int_{-\infty}^{\infty} f(x, y) \delta(x \cos \theta+y \sin \theta-t) d x d y
$$

Integral garis sepanjang sinar tomografi pada sudut $\theta$ dari sumbu $\mathrm{x}$ dan pada jarak $\mathrm{t}$ dari asal. Dengan memutar sistem kordinat (Gambar 3):

$$
\begin{gathered}
t=x \cos \theta+y \sin \theta \\
s=-x \sin \theta+y \cos \theta \\
x=t \cos \theta-s \sin \theta \\
y=t \sin \theta+s \cos \theta
\end{gathered}
$$

rekonstruksi citra didapatkan dengan cara mengembalikan nilai radon kepada sumbu $\mathrm{x}, \mathrm{y}$ dengan menggunakan invers radon:
Analisis citra hasil rekonstruksi dapat untuk mengenali dan mengukur area scale secara otomatis, kemudian sistem menghitung persentase area aliran fluida yang tersisa di dalam pipa. Fungsi boundary recognition digunakan untuk mengenali tepi bagian dalam dan bagian luar pipa. Untuk melakukan analisis diperlukan informasi dimensi obyek pipa yaitu diameter luar pipa dan ketebalan dinding pipa. Jumlah piksel area pipa (termasuk scale dan area aliran fluida) dikurang oleh jumlah area pipa dan scale (tanpa area aliran fluida) akan menghasilkan area aliran fluida yang tersisa akibat scale dalam piksel. Kemudian dengan memperhitungkan luas aktual area pipa dan ketebalan dinding pipa, maka didapatkan persentasi area aliran fluida yang tersisa akibat scaling dibanding dengan area aliran fluida pada pipa normal.

$$
\mu(x, y)=\int_{0}^{\pi} p_{\theta}(t) \int_{-\infty}^{\infty} \delta(x \cos \theta+y \sin \theta-t) d t d \theta
$$

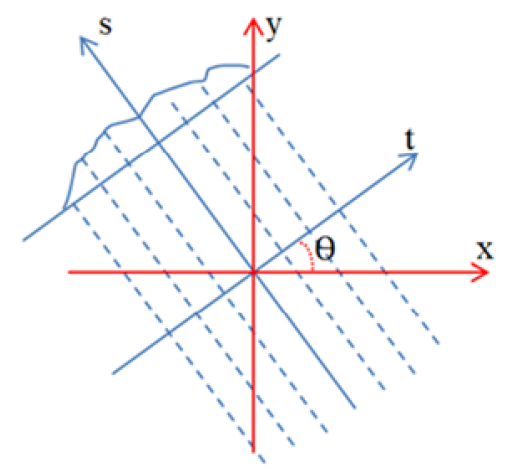

Gambar 3. Sumbu x dan y rekonstruksi citra 
antara ketiganya. Hasil ini menunjukkan sistem dapat membedakan materi dengan perbedaan densitas yang relatif kecil $\left(0.1 \mathrm{~g} / \mathrm{cm}^{3}\right)$.
Data hasil pemindaian 128 proyeksi pada pipa geothermal, dikurangi menjadi 64, 32, dan 16 proyeksi kemudian dibangun menjadi citra.

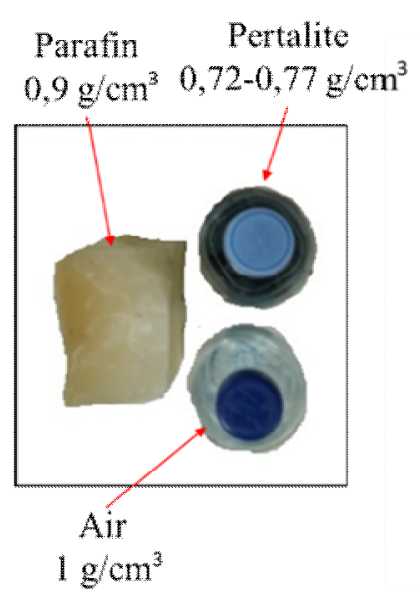

(a)

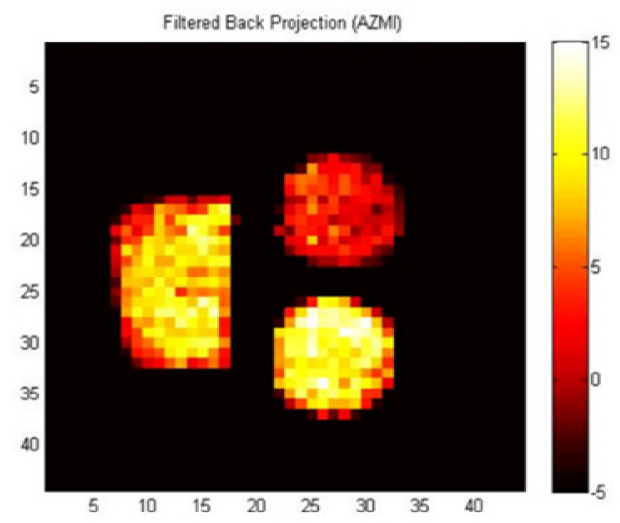

(b)

Gambar 4. (a) Air, parafin, dan pertalite, (b) citra hasil rekonstruksi 32 proyeksi

Percobaan kedua adalah pemindaian sample pipa geothermal plant (PLTP). Diameter pipa adalah $275 \mathrm{~mm}$ dengan ketebalan dinding $10 \mathrm{~mm}$. Pada percobaan ini dilakukan pemindaian sebanyak 128 proyeksi. Citra hasil rekonstruksi mengidentifikasi dinding pipa, scale, dan area aliran fluida (void) seperti ditunjukkan pada Gambar 5. Ketebalan dinding maupun profil scale pada pipa fit dengan citra hasil rekonstruksi.
Percobaan ini bertujuan untuk mengetahui efek dari jumlah proyeksi terhadap citra hasil rekonstruksi. Gambar 6 menunjukkan perbedaan citra hasil rekonstruksi. Pada 16 proyeksi terlihat bintik di luar pipa maupun di dalam void pipa. Pada citra 32 proyeksi masih terdapat sedikit bintik di luar dan di dalam pipa. Pada citra 64 dan 128 proyeksi tidak terdapat bintik di luar dan di dalam pipa, akan tetapi citra hasil rekonstruksi

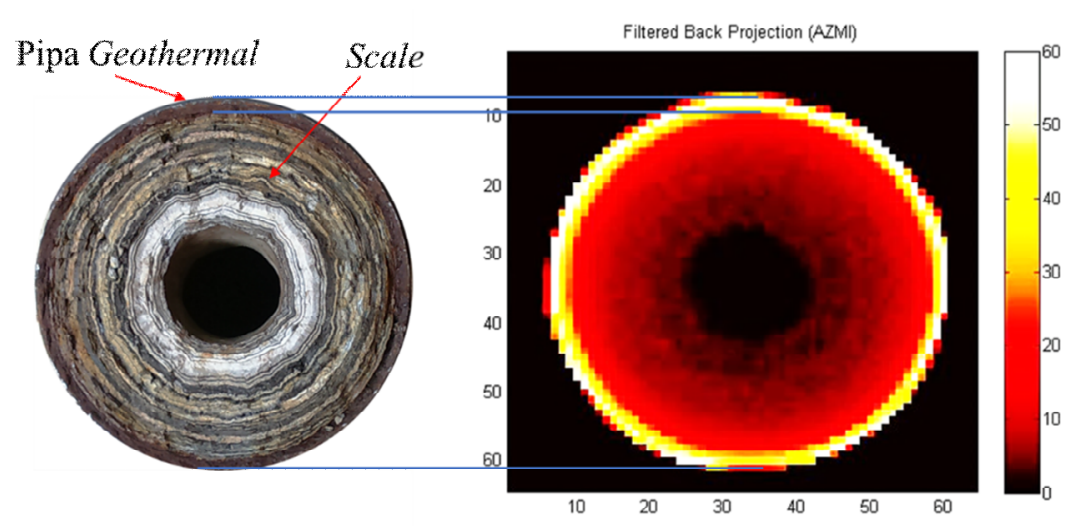

(a)

(b)

Gambar 5. (a) Pipa geothermal, (b) citra hasil rekonstruksi 128 proyeksi 
dari 128 proyeksi terlihat lebih halus dan lebih kontras dibandingkan dengan citra hasil rekonstruksi lainnya.

Untuk mendapatkan data 128 proyeksi dari pipa geothermal dibutuhkan waktu yang cukup lama (9 jam). Waktu yang dibutuhkan tergantung pada dimensi obyek yang akan dipindai, jumlah proyeksi, dan interval pemindaian translasi. Hal ini disebabkan karena sistem masih menggunakan metode pemindaian parallel beam (menggunakan 1 sumber radiasi dan 1 detektor). Metode pemindaian fan beam (1 sumber radiasi dan multi detektor) bisa menjadi solusi untuk mengatasi masalah waktu pemindaian obyek. Jika sistem menggunakan 10 detektor, maka waktu yang diameter $170 \mathrm{~mm}$ dengan ketebalan dinding 10 $\mathrm{mm}$. Pada percobaan ini dilakukan pemindaian sebanyak 32 proyeksi. Citra hasil rekonstruksi ditunjukkan pada Gambar 7. Teramati citra hasil rekonstruksi fit dengan obyek pipa yang dipindai.

\section{Analisis citra}

Citra hasil rekonstruksi dianalisis untuk menghitung area aliran fluida yang tersisa setelah terjadi scale pada pipa. Dengan menggunakan fungsi boundary recognition, maka didapatkan tepi luar dinding pipa dan tepi dalam scale pada pipa (Gambar 8 (a)). Luas area scale didapatkan dengan cara menghitung area seluruh pipa (Gambar 8 (b)) dikurangi dengan luas area pipa
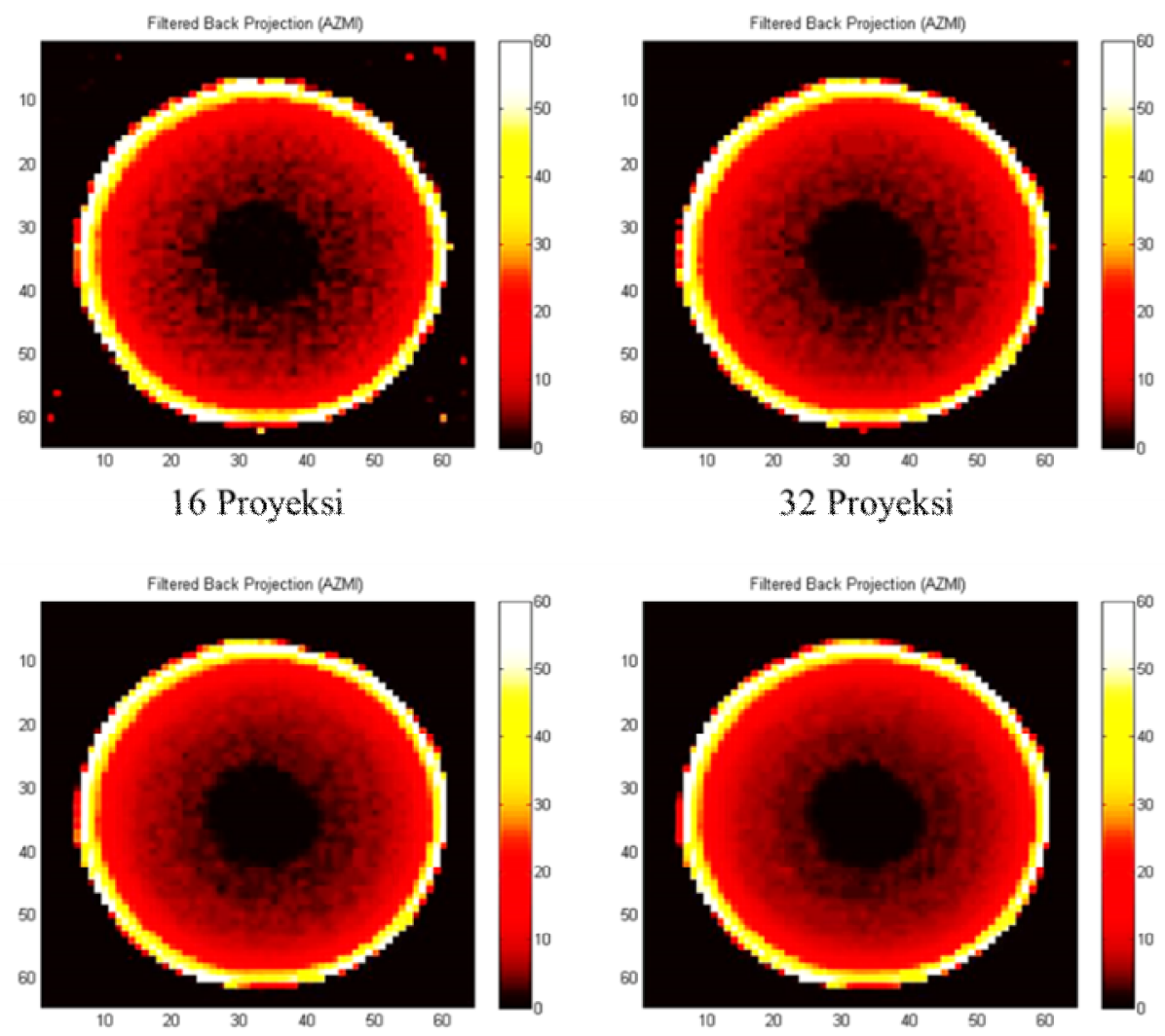

64 Proyeksi

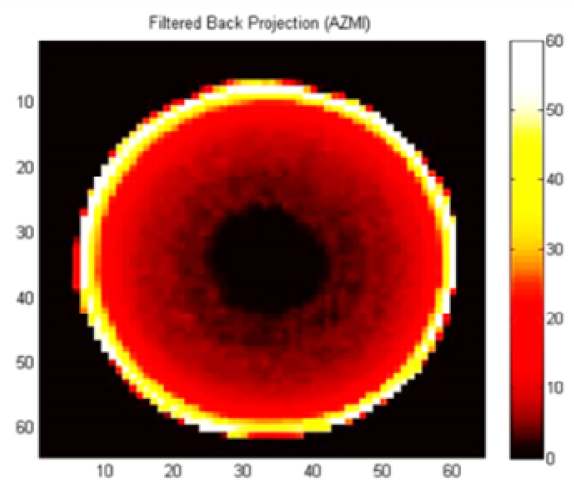

128 Proyeksi

Gambar 6. Citra hasil rekonstruksi pipa geothermal dari 16, 32, 64, dan 128 proyeksi

dibutuhkan untuk memindai obyek akan menjadi sepersepuluh dari waktu yang dibutuhkan dengan menggunakan 1 detektor.

Percobaan ketiga adalah pemindaian sampel pipa furnace berbentuk elbow. Pipa ini memiliki dan scale (Gambar 8 (c)). Kemudian didapatkan persentase area aliran fluida terkini (dengan scale) dibanding dengan area aliran fluida normal (tanpa scale) seperti ditunjukkan pada Gambar 8 (d). 


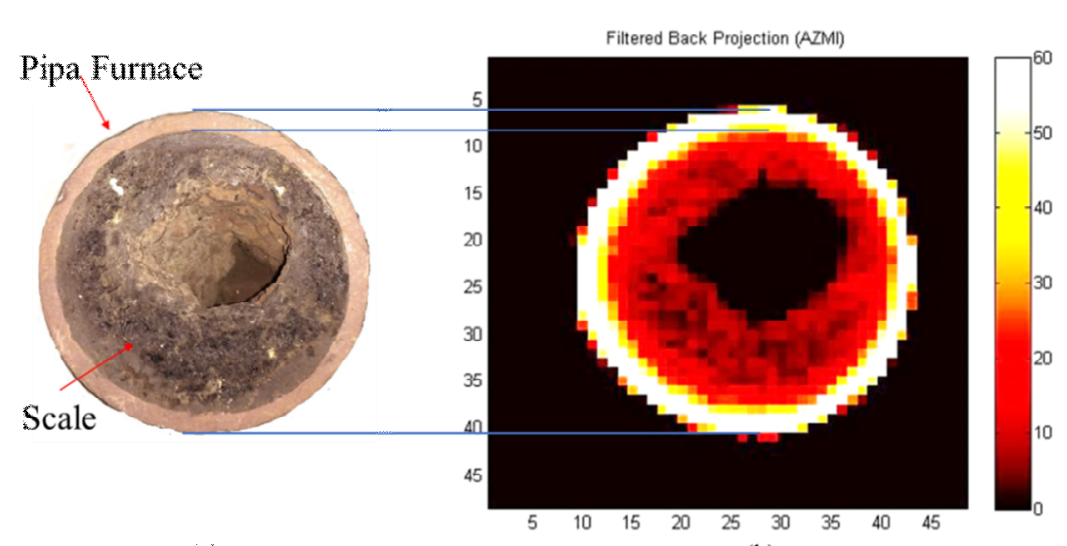

(a)

(b)

Gambar 7. (a) Pipa furnace, (b) citra hasil rekonstruksi 32 proyeksi

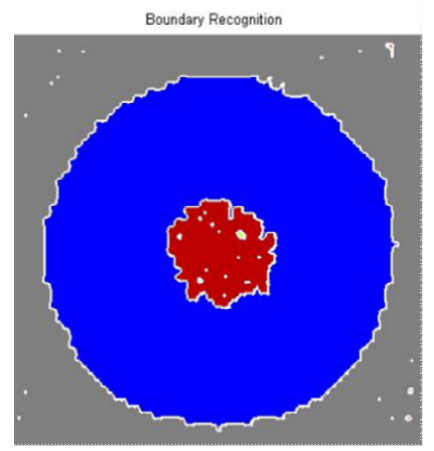

(a)

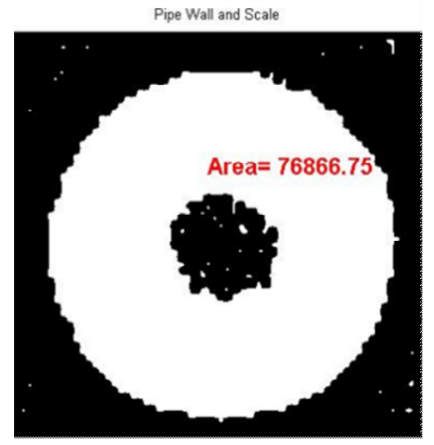

(c)

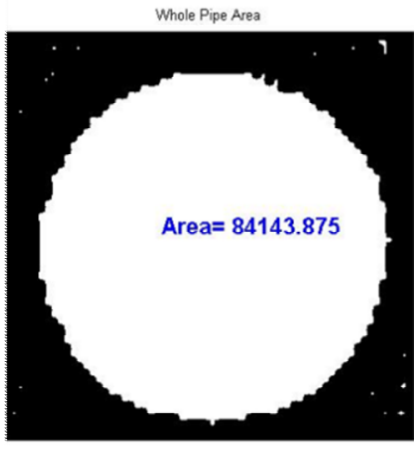

(b)

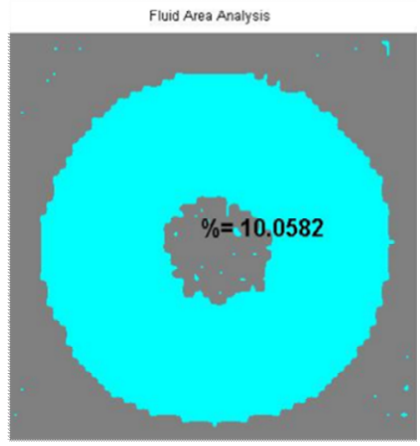

(d)

Gambar 8. Analisis citra pipa geothermal 16 proyeksi (a) boundary recognition, (b) whole pipe

Analisis citra pipa geothermal dilakukan terhadap citra hasil rekonstruksi 16, 32, 64, dan 128 proyeksi. Hasil analisis citra seperti ditunjukkan pada Gambar 9 dan Tabel 2. Terdapat perbedaan hasil analisis citra dikarenakan kualitas citra yang dianalisis. Pada citra 16 proyeksi area aliran fluida yang tersisa adalah $10,06 \%$. Hasil ini relatif jauh berbeda dibanding citra 32,64 , dan 128 berturut-turut yaitu $9,86 \%, 9,75 \%$, dan
9,76\%. Hal ini disebabkan oleh citra hasil rekonstruksi 16 proyeksi memiliki resolusi spasial yang kurang baik dibanding dengan citra dari proyeksi yang lebih banyak.

Analisis kedua dilakukan terhadap citra pipa furnace. Hasil analisis ditunjukkan pada Gambar 10. Didapatkan 26,08 persen area aliran fluida yang tersisa yang disebabkan oleh scaling. 


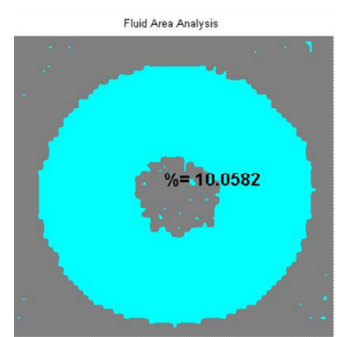

16 Proyeksi Fluid Area Analysis

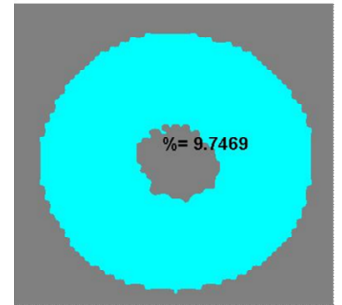

64 Proyeksi

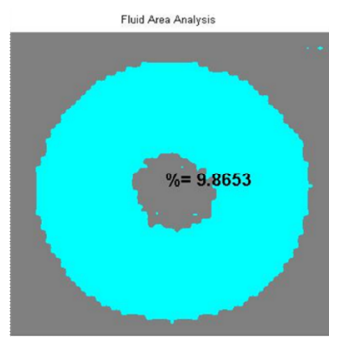

32 Proyeksi

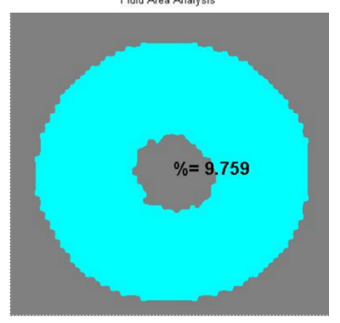

128 Proyeksi

Gambar 9. Persentase area aliran fluida yang tersisa dari pipa geothermal dari citra $16,32,64$, dan 128 proyeksi.

Tabel 2. Hasil Analisis Citra Pipa Geothermal Plant.

\begin{tabular}{cccc}
\hline Proyeksi & Area Pipa (Piksel) & $\begin{array}{c}\text { Area Dinding Pipa } \\
\text { dan Scale }\end{array}$ & $\begin{array}{c}\text { Area Fluida } \\
(\%)\end{array}$ \\
\hline 16 & 84143,88 & 76866,75 & 10,06 \\
32 & 83672,38 & 76574,88 & 9.86 \\
64 & 83677,50 & 76664,75 & 9,75 \\
128 & 83548,00 & 76537,36 & 9,76 \\
\hline
\end{tabular}

Boundary Recognition

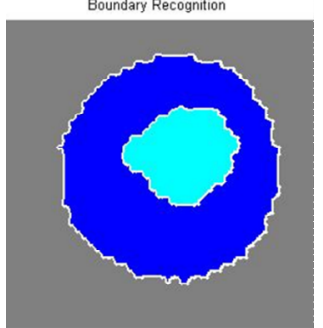

(a)

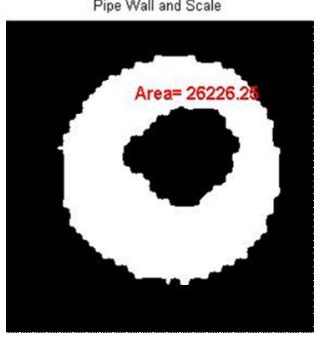

(c)

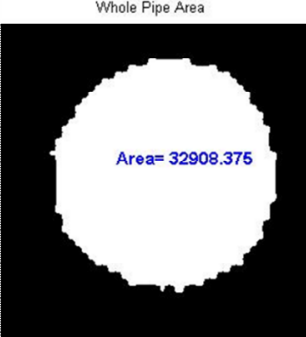

(b)

Fluid Area Analysis

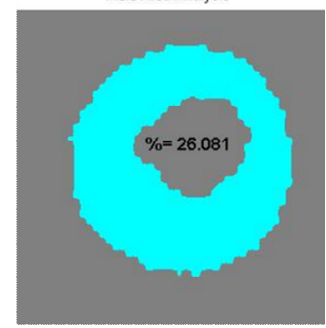

(d)

Gambar 10. Analisis citra pipa furnace 32 proyeksi (a) boundary recognition, (b) whole pipe area, (c) pipe wall and scale, dan (d) fluid area percentage 


\section{KESIMPULAN}

Sistem yang telah dibangun berhasil memindai obyek, mengakuisisi dan mengumpulkan data, serta membangun dan menganalisis citra untuk menginvestigasi scale di dalam pipa. Pemindaian menggunakan sumber radiasi gamma ${ }^{137} \mathrm{Cs}$ mampu membedakan material dengan nilai densitas yang berdekatan seperti air $\left(1 \mathrm{~g} / \mathrm{cm}^{3}\right)$, parafin $\left(0,9 \mathrm{~g} / \mathrm{cm}^{3}\right)$ maupun pertalite $\left(0,72-0,77 \mathrm{~g} / \mathrm{cm}^{3}\right)$. Algoritma analisis citra berhasil mengenali obyek pipa dan scale di dalamnya. Hasil analisis citra area fluida yang tersisa pada pipa geothermal plant adalah 10,06\% dengan 16 proyeksi, 9,86\% dengan 32 proyeksi, 9,75\% dengan 64 proyeksi, dan $9,76 \%$ dengan 128 proyeksi, sedangkan $26,08 \%$ pada pipa furnace dengan 32 proyeksi.

\section{UCAPAN TERIMA KASIH}

Penulis mengucapkan terima kasih kepada Universitas Indonesia untuk dana penelitiannya dan Badan Tenaga Nuklir Nasional untuk dukungannya terhadap penelitian ini.

\section{DAFTAR PUSTAKA}

1. C.H. de Mesquita, A.F. Velo, D.V.S. Carvalho, J.F.T. Martins, and M.M. Hamada, "Industrial tomography using three different gamma ray," Flow Meas. Instrum., vol. 47, pp. 1-9, 2016.

2. F.N. Kemmer, The Nalco Water Hand Book. The Nalco Chemical Co. Mc Graw Hill Book Co, 2nd ed. New York, 1979.

3. E. Gunnlaugsson, H. Armannsson, S. Thorhallsson, and B. Steingrimsson, "Problems in Geothermal Operation Scaling and Corrotion," Short Course VI Util. Low- Mediu. Geotherm. Resour. Financ. Asp. Util., pp. 1-18, 2014.
4 M. Syahri and B. Sugiarto, "Scale Treatment Pada Pipa Distribusi Crude Oil Secara Kimiawi," vol. 104, no. 274, pp. 33-37.

5. J.S. Charlton, Radioisotope Techniques for Problem-solving in Industrial Process Plants. Leonard Hill, 1986.

6. A.C. Kak and M. Slaney, Principles of Computerized Tomographic Imaging. 1987.

7. J. Kim, S. Jung, J. Moon, and G. Cho, "Industrial gamma-ray tomographic scan method for large scale industrial plants," Nucl. Instruments Methods Phys. Res. Sect. A Accel. Spectrometers, Detect. Assoc. Equip., vol. 640, no. 1, pp. 139150, 2011.

8. J. Kim, S. H. Jung, J. Moon, J. G. Park, J. Jin, and G. Cho, "Development of transportable gamma-ray tomographic system for industrial application," Nucl. Instruments Methods Phys. Res. Sect. A Accel. Spectrometers, Detect. Assoc. Equip., vol. 693, pp. 203-208, 2012.

9. Glenn F. Knoll, Radiation Detection and Measurement, 2nd ed. John Wiley \& Sons, Ltd, 2010.

10. J. Abdullah, M. C. F. Cassanello, M. P. Dudukovic, T. Dyakowski, M. M. Hamada, J. H. Jin, G. a. Johansen, J. B. Kim, S. a. Legoupil, R. Maad, C. . Mesquita, J. Nowakowski, F. P. Ramirez-Garcia, D. Sankowski, S. M. Sipaun, and J. Thyn, "Industrial Process Gamma Tomography," IAEA-Tecdoc1589, 2008.

11. G.T. Herman, Advances in Pattern Recognition - Fundamentals of Computerized Tomography, Second ed. Springer, 2009. 
Jurnal Ilmiah Aplikasi Isotop dan Radiasi

A Scientific Journal for The Applications of Isotopes and Radiation

p ISSN 1907-0322

Vol. 13 No. 1 Juni 2017

e ISSN 2527-6433 